\title{
Partitioning of the water soluble versus insoluble fraction of trace elements in the city of Santiago, Chile
}

\author{
María A. RUBIO ${ }^{1 *}$, Karen SÁNCHEZ ${ }^{1,2}$, Pablo RICHTER ${ }^{2}$, Jorge PEY ${ }^{3,4}$ and Ernesto GRAMSCH ${ }^{5}$ \\ ${ }^{1}$ Facultad de Química y Biología, y Centro para la Nanociencia y la Nanotecnología (CEDENNA), Universidad de \\ Santiago de Chile, Casilla 40, Correo 33, Santiago, Chile. \\ ${ }^{2}$ Facultad de Ciencias Químicas y Farmacéuticas, Universidad de Chile, Casilla 233, Santiago, Chile. \\ ${ }^{3}$ Instituto Geológico y Minero de España (IGME), Zaragoza, España. \\ ${ }^{4}$ Instituto de Diagnóstico Ambiental y Estudios del Agua (IDAEA-CSIC), Barcelona, España. \\ ${ }^{5}$ Facultad de Ciencia, Universidad de Santiago de Chile, Casilla 40, Correo 33, Santiago, Chile \\ *Corresponding author: maria.rubio@usach.cl
}

Received: December 18, 2017; accepted: August 17, 2018

\begin{abstract}
RESUMEN
Se investigó la composición elemental total y la fracción soluble en agua de $\mathrm{PM}_{10}$ en tres áreas urbanas diferentes de Santiago de Chile, del centro a los suburbios. Las muestras de $\mathrm{PM}_{10}$ recogidas durante el mes de mayo (mediados del otoño en el hemisferio sur) en 2006, 2008, 2009 y 2010 fueron analizadas para metales mayores y trazas, y la partición entre fracciones insolubles y solubles se determinó para la mayoría de ellos. Las concentraciones medias de $\mathrm{PM}_{10}$ variaron de $71 \mu \mathrm{g} \mathrm{m}^{-3}$ (Cerrillos) a $128 \mu \mathrm{g} \mathrm{m}^{-3}$ (La Pintana), valores que se encuentran dentro de los rangos estacionales observados en Santiago. Se cuantificaron 25 elementos principales y trazas (Fe, Al, Ca, K, Mg, P, Pb, S, Ti, Mn, Cu, Zn, Ba, Zr, Cr, As, Sn, Sb, Ni, V, Li Co, Cd, La y Rb) en el presente estudio. $\mathrm{Ba}, \mathrm{Sb}, \mathrm{Cd}$, As y $\mathrm{Zn}$ fueron los elementos más solubles, con proporciones que varían de $50 \%$ a $98 \%$ de solubilidad. Por el contrario, los oligoelementos menos solubles fueron Ti, Sn, $\mathrm{Pb}$ y $\mathrm{Cr}$. La mayor parte de los metales traza de alta solubilidad no están solamente fuertemente ligados a la emisión de tubos de escape vehiculares, sino a emisiones vehiculares como el sistema de frenos o a ciertas fuentes industriales. Nuestros resultados evidencian la cantidad significativa de oligoelementos solubles en la atmósfera urbana de Santiago clasificados como tóxicos y/o carcinógenos, lo que sugiere un impacto no despreciable en la salud.
\end{abstract}

\begin{abstract}
The total elemental composition and the water-soluble fraction of $\mathrm{PM}_{10}$ from three different urban areas in Santiago, Chile, from downtown to the suburbs, were investigated. $\mathrm{PM}_{10}$ samples collected during the month of May (mid-autumn in the Southern Hemisphere) in 2006, 2008, 2009, and 2010 were analyzed for major and trace metals, and the partitioning between the insoluble and soluble fractions was determined for most of them. $\mathrm{PM}_{10}$ average concentrations ranged from $71 \mu \mathrm{g} \mathrm{m}^{-3}$ (Cerrillos) to $128 \mu \mathrm{g} \mathrm{m}^{-3}$ (La Pintana), which are within the seasonal ranges observed in Santiago. Twenty five major and trace elements (Fe, $\mathrm{Al}, \mathrm{Ca}, \mathrm{K}$, $\mathrm{Mg}, \mathrm{P}, \mathrm{Pb}, \mathrm{S}, \mathrm{Ti}, \mathrm{Mn}, \mathrm{Cu}, \mathrm{Zn}, \mathrm{Ba}, \mathrm{Zr}, \mathrm{Cr}, \mathrm{As}, \mathrm{Sn}, \mathrm{Sb}, \mathrm{Ni}, \mathrm{V}, \mathrm{Li}, \mathrm{Co}, \mathrm{Cd}, \mathrm{La}$, and $\mathrm{Rb}$ ) were determined in the present study. $\mathrm{Ba}, \mathrm{Sb}, \mathrm{Cd}, \mathrm{As}$, and $\mathrm{Zn}$, with proportions in the soluble fraction varying from $50 \%$ to $98 \%$, were the most soluble elements. On the contrary, the less soluble trace elements were Ti, $\mathrm{Sn}, \mathrm{Pb}$, and $\mathrm{Cr}$. Most of the high-solubility trace metals are strongly linked to non-exhaust traffic emissions, as well as to certain industrial sources. Our results evidence the significant amount of soluble trace elements in Santiago's urban atmosphere classified as toxic and/or carcinogenic, thus suggesting a non-negligible health impact.
\end{abstract}

Keywords: Megacity, $\mathrm{PM}_{10}$, trace metals, road traffic, atmospheric pollution. 


\section{Introduction}

Santiago, the capital of Chile, is one of the cities with the highest atmospheric pollution levels in Latin America and among the most polluted worldwide, similar to Mexico City, Delhi, or Beijing (Molina and Molina, 2004; WHO, 2013). The city of Santiago concentrates $40 \%$ of the country's population, with around six million inhabitants and a population density of 450 people per $\mathrm{km}^{2}$ (INE, 2017). The increasing urban population, together with the geographic location and prevailing weather conditions (unfavorable for ventilation) account for such high levels of atmospheric pollution (Toro et al., 2014). In spite of the adoption of certain abatement measures to reduce such high atmospheric pollution levels, which included the renewal of public transport, the improvement of the chemical quality of fuels by decreasing their proportion of sulfur, benzene, olefins, and aromatic compounds, the renewal of the truck fleet, the implementation of standards for light vehicles and industry, or the adoption of mitigation actions in dust production, $\mathrm{PM}_{10}$ and $\mathrm{PM}_{2.5}$ concentrations are still above national air quality standards, especially during the autumn and winter months (www.sinca.mma.gob.cl) (Mena-Carrasco et al., 2014). Those measures have been progressively implemented since 1997.

Atmospheric particulate matter is a pollutant whose analysis can be addressed from different perspectives and/or attending to diverse characteristics, including mass concentrations, size distribution, particle shape or chemical composition. These characteristics are strongly related to the kinds and magnitudes of the effects on health (Pope and Dockery 2006; Franklin et al., 2008; Sarnat et al., 2008; Bell et al., 2009; Peng et al., 2009; Ostro et al., 2011). Particulate matter may arise from different natural and anthropogenic sources, and its chemical composition is usually well connected with its origin. A number of studies have been published on the chemical composition of particulate matter in Santiago (Prendez et al., 1984; Didyk et al., 2000; Gil et al., 2000; Jorquera 2002; Koutrakis et al., 2005; Gramsch et al., 2006, 2009), and specific ones on the elemental chemical composition of $\mathrm{PM}_{10}$ (Artaxo et al., 1999; Richter et al., 2007; Sax et al., 2007). The fine particulate matter $\left(\mathrm{PM}_{2.5}\right)$ of Santiago has a predominance of secondary organic and inorganic aerosols, reaching up to $60 \%$ (Seguel et al., 2009). During the last few years, as a result of the implementation of certain measures to reduce PM levels, the elemental composition of PM in the city of Santiago has substantially changed. There has been an important decrease of sulfur and lead, due to the substantial improvement of the quality of fuels (desulfurization) and the use of unleaded gasoline. A similar pattern is seen with bromine. Inorganic substances, including trace metals, have been determined (Jorquera and Barraza, 2012). In particular, a study over an industrial district in Santiago during 19972003 showed that the labile or water-soluble fraction of $\mathrm{PM}_{10}$ has relatively high concentrations of copper, zinc, manganese, cadmium and arsenic, elements clearly associated to anthropogenic emissions (industry, road traffic). Overall, a decline in PM concentrations has taken place in Santiago since 2000. Toro et al. (2014) studied the variability of particulate matter from 2000 to 2012 at four locations in the metropolitan region of Santiago. While the $\mathrm{PM}_{10}$ and $\mathrm{PM}_{2.5}$ levels have declined since 2000, they still exceed the environmental quality standards. Annual average $\mathrm{PM}_{10}$ concentrations range from 52 to $76 \mu \mathrm{g} \mathrm{m}^{-3}$, with the highest concentrations in winter.

It has been shown that fine particulate matter is responsible for increased mortality and morbidity of people in Santiago. Cakmak et al. (2007, 2009, 2011) and Valdés et al. (2012) concluded that the $\mathrm{PM}_{2.5}$ mass is not enough to explain the observed incidence of mortality, and they claimed for specific studies to identify the main sources of heavy metals such as $\mathrm{Zn}, \mathrm{Cr}$ or $\mathrm{Cu}$.

As discussed before, the chemical composition of PM is a better proxy than PM mass concentrations to assess health impacts. Furthermore, if we could introduce another parameter, such as the partitioning of trace elements between soluble and insoluble fractions, the epidemiological effects linked to particulate matter pollution could be better constrained.

The objective of this work was to determine the total elemental composition and the water-soluble fraction of so called heavy and trace elements present in $\mathrm{PM}_{10}$ from three urban locations under different emission or source patterns in Santiago: downtown Santiago, a peripheral area, and an intermediate locations between the former. The choice of years for the study (2006, 2008, 2009 and 2010) is justified by a change in the type of public transport to one called 
Transantiago (Gramsch et al., 2013), which replaced old buses with new ones fitted with nonpolluting technology, reduced circulation times and the number of vehicles, and established the use of exclusive lanes. However, the pattern of combustion sources has also varied in Santiago, especially over the last five years. Important sources of emission of fine PM are residential quarters, accounting for almost $30 \%$, together with mobile sources. (Troncoso et al., 2012; MMA, 2014; Villalobos et al., 2015).

\section{Experimental}

\subsection{Sampling zone}

This study used samples from three monitoring stations in Santiago, located in Cerrillos (CR), La Pintana (LP) and Av. Ossa (OSS). The choice of these sites was due to the following: Cerrillos (lat. -33.491 , long. -70.719 , $21 \mathrm{~km}^{2}$ and 83000 inhabitants) is an industrial zone in the west side of the city; La Pintana (lat. -33.614 , long. $-70.635,30.6 \mathrm{~km}^{2}$ and 287000 inhabitants) is a peripheral urban site, and Av. Ossa (lat. -33.449, long. $-70.571,16.9 \mathrm{~km}^{2}$ and 170000 inhabitants) is an intermediate area between the above. $\mathrm{PM}_{10}$ samples were obtained during the month of May (autumn) in 2006, 2008, 2009 and 2010. The choice of month is justified from previous studies (Jorquera, 2002; Gramsch et al., 2006), which found that May is a month with winter-like conditions (low temperatures, low wind speed and strong temperature inversions) but with little rain, so it is a time period in which environmental conditions do not change much. Figure 1 shows the location of these monitoring sites.

The wind pattern in Santiago de Chile has a valley-mountain behavior with generally low speeds. The predominant wind in the city occurs during the afternoon (11-19 LT) with a south-east direction, as shown in the wind roses of Figure 2. It can be seen that during the afternoon, the wind direction is the same for all stations and has little dispersion. During these hours, the speed is also higher than during the night or early morning. There is also a very clear difference between the day and night wind. Figure 3 shows the wind speed for all sites for the month of May 2009. The wind comes from the coast and enters Santiago from the south-west, therefore the highest speed is achieved in Cerrillos (see Fig. 3), and its velocity decreases as it enters the city. This wind brings

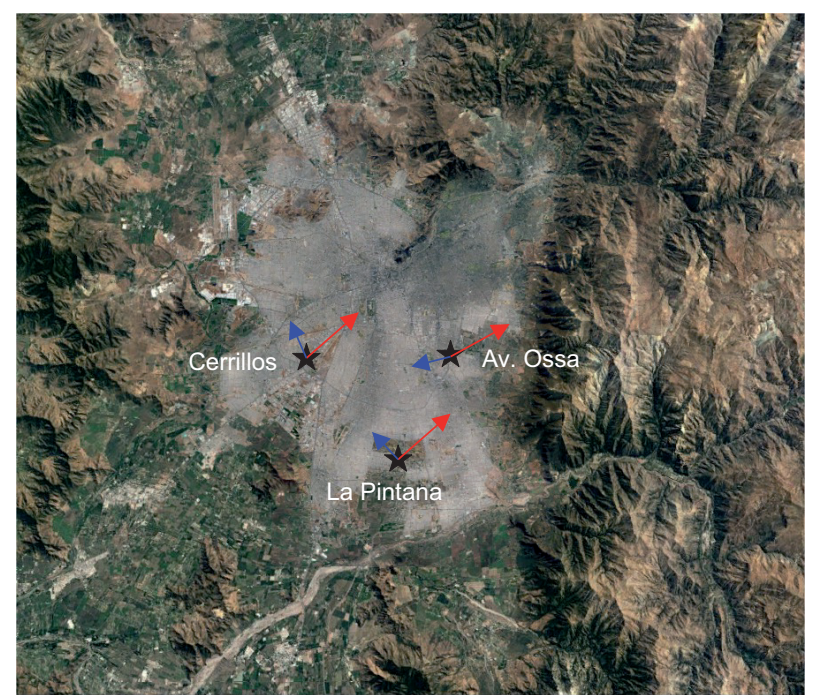

Fig.1. Map of Santiago, Chile, with the location of the three monitoring stations used for the study: Cerrillos (lat. -33.491 , long. -70.719 , located in the west of the city); La Pintana (lat. -33.614 , long. -70.635 , a peripheral urban site), and Av. Ossa. (lat. -33.449 , long. -70.571 , an intermediate area). The red arrows indicate the predominant wind direction during the afternoon (11-19 LT) and the blue arrows show the wind direction at night and early morning.

clean air from the coast into the city (Gramsch et al., 2006) but it also carries pollutants from downtown Santiago towards the east. As shown in Figure 3, pollutants from La Pintana can be transported into Av. Ossa during the afternoon. At night and early morning, the wind direction reverses; however, the velocity is very low and the direction is not the opposite of the afternoon wind. Thus, there is probably no transport of pollutants from Av. Ossa towards the other sites at night.

\subsection{Materials and methods}

$\mathrm{PM}_{10}$ was collected on fiberglass filters $(20.32 \times$ $25.4 \mathrm{~cm}$ ) during $24 \mathrm{~h}$, using hi-vol. samplers (ECOTECH model 3000) which absorbed $1600 \mathrm{~m}^{3}$ of air in $24 \mathrm{~h}$. All samples were provided and normalized by the Ministerio del Ambiente (Ministry of the Environment, www.mma.gob.cl) in collaboration with Chile's Ministerio de Salud (Ministry of Health).

Then, circular sections of each filter $\left(1.53 \mathrm{~cm}^{2}\right)$ were obtained and merged to build-up a weekly composite sample. Overall, four samples were obtained 

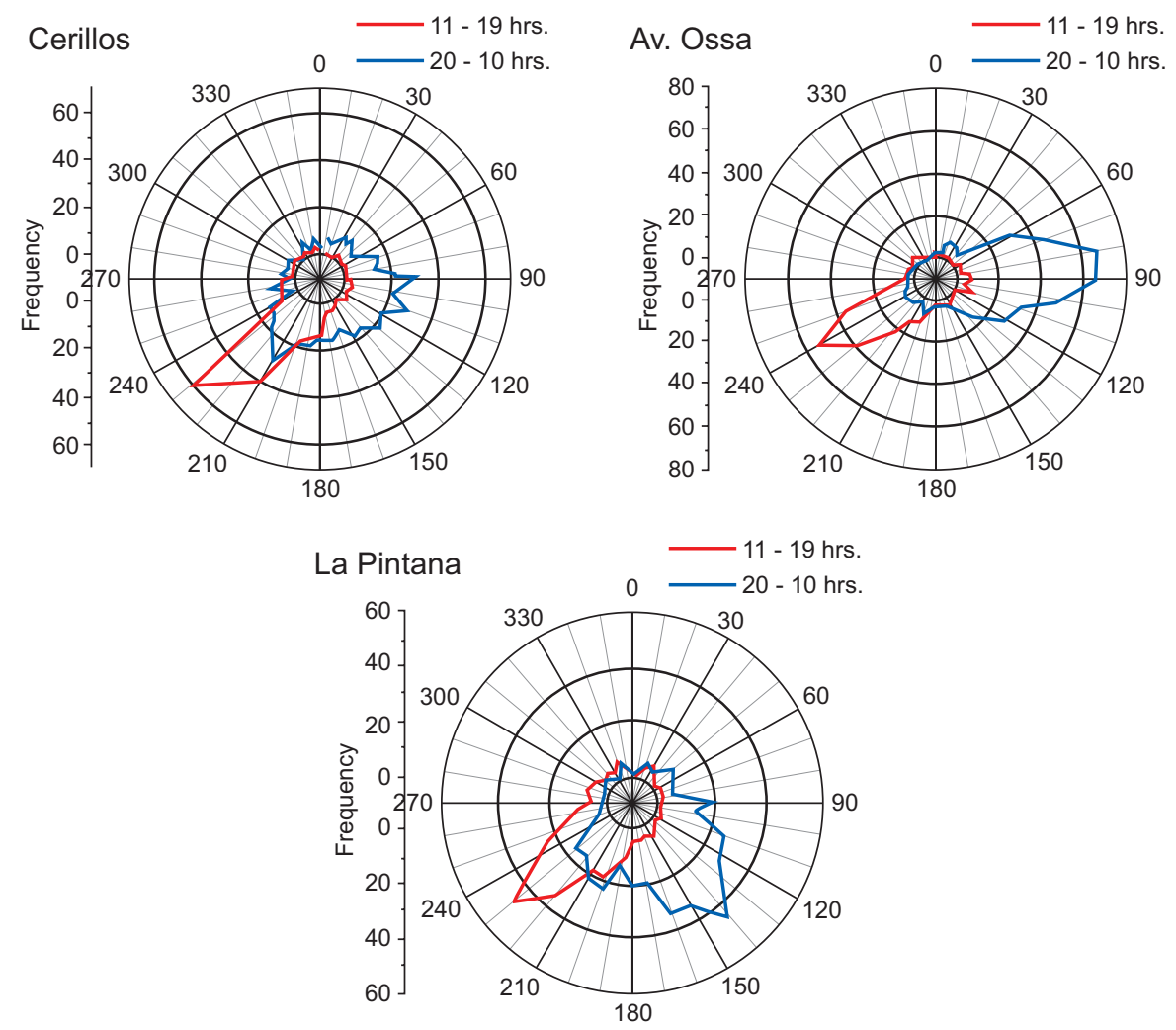

Fig. 2. Average wind roses in La Pintana, Cerrillos and Av. Ossa for May 2009. The red lines show the wind direction between 11 and 19 LT and the blue lines show the wind direction during the rest of the day.

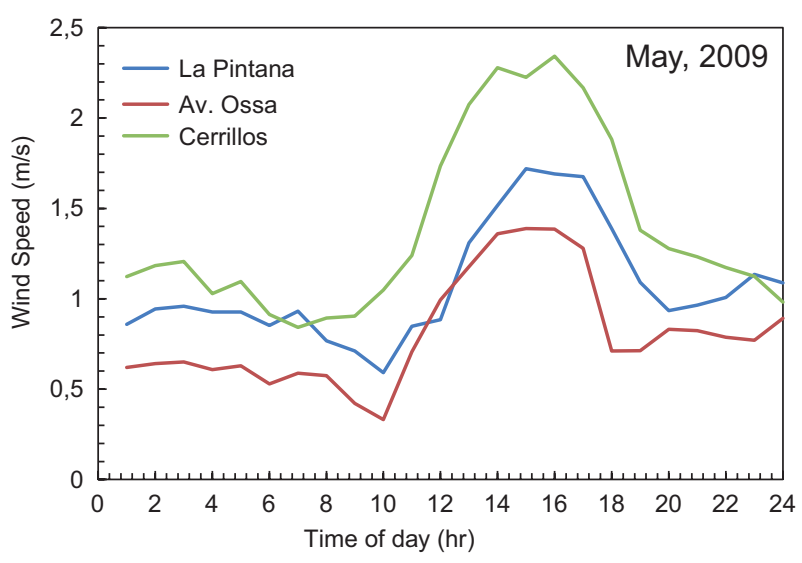

Fig. 3. Average wind speed in the three sites for May 2009.

per year at each urban observatory. The sampling was made in duplicate, analyzing 48 samples and 48 counter-samples.

\subsection{Total metals extraction}

Total metals extraction from the filters was carried out by the acid digestion in Teflon containers (EPA method). The samples were digested with $1.25 \mathrm{~mL}$ of nitric acid (Suprapur, Merck) and $2.5 \mathrm{ml}$ of hydrochloric acid (Suprapur, Merck), and heated at $90{ }^{\circ} \mathrm{C}$ during $12 \mathrm{~h}$. Then, $1.25 \mathrm{~mL}$ of $\mathrm{HClO}_{4}$ was added and the mixture was heated for 3 to $6 \mathrm{~h}$ to dryness at $240{ }^{\circ} \mathrm{C}$ on a hotplate. The final residue was re-dissolved with $2.5 \mathrm{~mL}$ of nitric acid and the volume was completed to $25.0 \mathrm{~mL}$ with ultra-pure water. Finally, the solution was centrifuged for $20 \mathrm{~min}$ at $5000 \mathrm{rpm}$ and stored at $4{ }^{\circ} \mathrm{C}$ until the chemical analysis was performed. Thereafter, the solutions were analyzed using an ICP-MS (X series II, THERMO).

In order to account for the filter contribution to individual concentrations of the elements and to ensure the analytical quality of our determinations, each set of samples was carried out together with a 
number of blank filters and a blank filter with $0.01 \mathrm{~g}$ of a fly-ash reference material with certified concentrations (NIST-1633b).

The values in micrograms per liter were expressed in nanograms per cubic meter considering the volume of air absorbed during $24 \mathrm{~h}$, the impact area of the filter $\left(513 \mathrm{~cm}^{2}\right)$, the particular area of the filters used for the analysis $\left(1.53 \mathrm{~cm}^{2}\right)$, and the number of filters analyzed.

\subsection{Extraction of the soluble fraction of major trace elements}

A duplicate of each composite sample was leached with $30 \mathrm{~mL}$ of ultrapure water inside PVC containers. The containers were then immersed in an ultrasonic bath during $10 \mathrm{~min}$ and placed in an oven at $60^{\circ} \mathrm{C}$ for $6 \mathrm{~h}$. The resultant solution was filtered through a 0.45 $\mu \mathrm{m}$ membrane filter, and finally analyzed by ionic chromatography (high performance liquid chromatography using a WATERS IC-pakTM anion column) for the determination of $\mathrm{Cl}^{-}, \mathrm{NO}_{3}{ }^{-}$and $\mathrm{SO}_{4}{ }^{2-}$, and by a specific electrode (WATERS 432 conductivity detector) to obtain $\mathrm{NH}_{4}{ }^{+}$concentrations. Ten $\mathrm{mL}$ of the former solution were acidified with nitric acid (5\%) and analyzed by ICP-AES to obtain the concentration of major and trace elements in the solution.

\subsection{Statistical analysis}

The number of samples was insufficient to run typical receptor models such as positive matrix factorization
(PMF). Hence, in this study the statistical analysis of the results was based on cluster analysis (CA), considering the total element concentrations. Data standardization of each variable was performed prior to statistical analysis because the concentration orders among the elements and the parameters differed greatly, and statistical results would be highly biased by elements with high concentration. The furthest neighbor method was applied for grouping of the different variables, and dissimilarity was defined by the square Euclidean distance. With this method we were not able to obtain sources and/or atmospheric processes; however, the results should be indicative of possible element associations when source apportionment studies are conducted.

\section{Results and discussion}

\subsection{PM mass concentrations}

In Santiago, Chile, $\mathrm{PM}_{10}$ concentrations have decreased continuously since 1998 , but the trend has slowed down since 2010. Figure 4a shows the $\mathrm{PM}_{10}$ yearly average for the nine stations belonging to the air pollution network of the Sistema de Información Nacional de Calidad del Aire (National Air Quality Information System, SINCA) inside Santiago (SINCA, 2018). This network is used by the authority to monitor several air pollutants as well as meteorological variables. $\mathrm{PM}_{10}$ is measured using TEOM monitors (Rupprecht \& Patachnick, Albany, NY, and Thermo

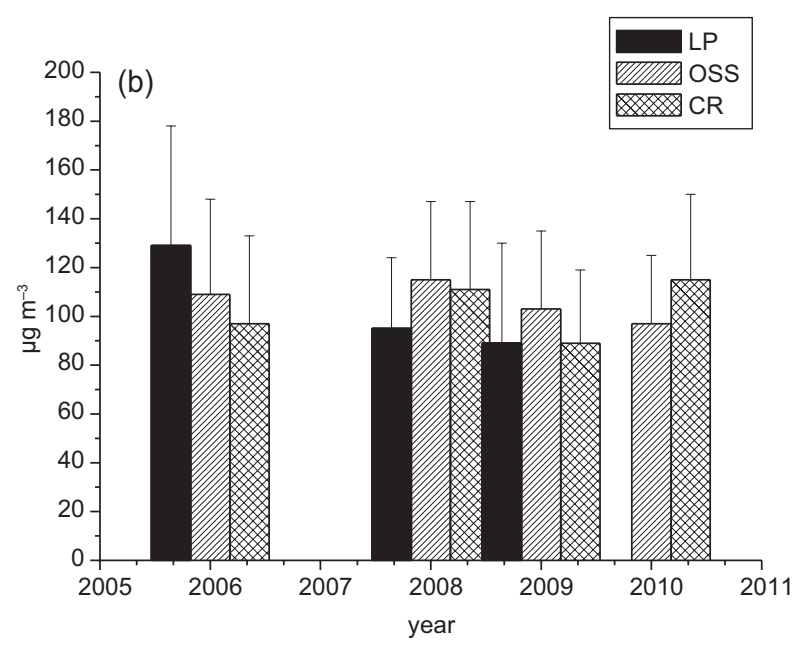

Fig. 4. (a) Evolution of the yearly $\mathrm{PM}_{10}$ average at the nine stations of the SINCA network in Santiago. (b) Evolution of average $\mathrm{PM}_{10}$ measured during May 2006, 2008, 2009, and 2010 for Cerrillos (CR), La Pintana (LP) and Av. Ossa (OSS). 
Fisher Scientific, Waltham, MA). From 2007 (70.3 $\mu \mathrm{g}$ $\left.\mathrm{m}^{-3}\right)$ to $2010\left(63.0 \mu \mathrm{g} \mathrm{m}^{-3}\right)$ there was a slight decrease in $\mathrm{PM}_{10}$, however this trend did not continue and $\mathrm{PM}_{10}$ has leveled since 2010, as shown in Figure 4a. In the three monitoring stations (Cerrillos [CR], La Pintana [LP] and Av. Ossa [OSS]) there has also been a slight decrease in concentrations from 2006 to 2010, as shown in Figure 4b. During these years important measures have been implemented to abate air pollution from public transport, which included the restructuring of the public transport system, the renewal of the vehicle fleet, and the shortening of circulation routes. These measures were somewhat unpopular, leading to a slight increase of private vehicles (around 6\% more in 2009 with respect to 2003 [INE 2011]). This result agrees partly with the report of the Sociedad Chilena de Políticas Públicas (Chilean Society of Public Policies), which notes that "the annual evolution of $\mathrm{PM}_{10}$ between 1997 and 2010 shows a decreasing but moderate trend, indicating that air quality has improved steadily over the past 15 years". However, as shown in Figure 4a, since 2010 the trend has decreased, and $\mathrm{PM}_{10}$ levels have been fairly constant (Moreno et al., 2010; Figuero et al., 2017).

\subsection{Major and trace elements in PM10: mean con- centrations and spatio-temporal variation}

The application of the analytical procedures described above has resulted in the determination and quatification of major and trace elements. Among the most abundant, $\mathrm{Fe}, \mathrm{Al}, \mathrm{K}, \mathrm{Ca}$, and $\mathrm{Mg}$ prevailed, with concentrations in the range 600-8000 $\mathrm{ng} \mathrm{m}^{-3}$ (Table I). These are mostly associated with mineral dust bot from natural and anthropogenic origins (but essentially from the latter) (Paris et al., 2010). Sources such as biomass burnig in the case of $\mathrm{K}$ (Cheng et al., 2013) or industrial emissions and brake abrasion in the case of Fe (Ulrich et al., 2012) may also contribute. Other abundant $\mathrm{PM}_{10}$ components are $\mathrm{S}$, mostly as sulfate salts (ammonium sulfate predominantly but also forming $\mathrm{Ca}$ and $\mathrm{Mg}$ sulfate compounds), at concentrations between 2000-4000 $\mathrm{ng} \mathrm{m}^{-3}$ (Table I) and phosporus, usually with concentrations in the range of 280-1600 $\mathrm{ng} \mathrm{m}^{-3}$ (Wang et al., 2015). As expected, lower abundances (usually under $100 \mathrm{ng}$ $\mathrm{m}^{-3}$ ) have been found for other elements, including heavy metals ( $\mathrm{Pb}, \mathrm{Ti}, \mathrm{Mn}, \mathrm{Cu}, \mathrm{Zn}, \mathrm{Ba}, \mathrm{Zr}, \mathrm{Cr}, \mathrm{As}, \mathrm{Sn}$,
$\mathrm{Sb}, \mathrm{Ni}, \mathrm{V}, \mathrm{Li}, \mathrm{Co}, \mathrm{Cd}, \mathrm{La}, \mathrm{Rb})$. Details on year- and site-specific average concentrations can be found in Table I.

Regarding water-soluble $\mathrm{PM}_{10}$ components (sulfate, nitrate, ammonium and chloride), Table II shows that the most abundant is ammonium, with concentrations between 0.42 and $0.21 \mu \mathrm{Eq} \mathrm{m}^{-3}$. Nitrate is the second compound in abundance, in the range of 0.38 to $0.19 \mu \mathrm{Eq} \mathrm{m}^{-3}$; followed by chloride, showing concentrations in the range of 0.12 to $0.08 \mu \mathrm{Eq} \mathrm{m}^{-3}$, and finally sulfate in the range of 0.10 to $0.05 \mu \mathrm{Eq} \mathrm{m}{ }^{-3}$. These results are not surprising: urban pollution episodes are generally characterized by huge quantities of secondary inorganic and organic components. Amongst the inorganic ones, ammonium nitrate is the foremost abundant component, mostly derived from the transformation in the atmosphere of combustion exhausts $\left(\mathrm{NO}_{\mathrm{x}}\right.$ to nitrates) from industry and vehicles.

Overall, the amount of major anions and cations, namely sulfate, nitrate, ammonium and chloride (Table II), accounts for $40-50 \%$ of $\mathrm{PM}_{10}$ mass concentrations. A good linear correlation between nitrates and ammonium was observed $(\mathrm{A}=0.0395$ $\pm 0.057 ; \mathrm{B}=1.015 \pm 0.199 ; \mathrm{R}=0.68707 \pm 0.10006$; $\mathrm{N}=31 ; \mathrm{p}<0.0001)$. If we take into account the soluble metallic cations, the cation to anion ratio is close to 1 , ensuring the neutrality of the particles.

In order to deal with the main characteristics of each monitoring site in terms of $\mathrm{PM}_{10}$ composition, in Figure 5 we have summarized some of the typical tracers for different sources. As seen in Figure 5a, a typical PM component such as sulfur was found to be homogeneously distributed among the sites during the specific annual campaigns, showing almost double concentrations in 2006 with respect to the period 2008-2010. Figure 5b displays year- and site-dependent concentrations of calcium, a typical mineral dust element. In this case, the highest concentrations were recurrently observed in Av. Ossa during the first two years, probably due to local influences such as construction activities. Thereafter, Ca concentrations remained comparable in all sites. Figure 5c shows year- and site-dependent concentrations of vanadium and nickel, as traces of fuel-oil combustion. This particular PM source seems to be of a regional nature, with a slight enrichment towards La Pintana in the first two years, probably due to the location of some industries in which heavy oil combustion 


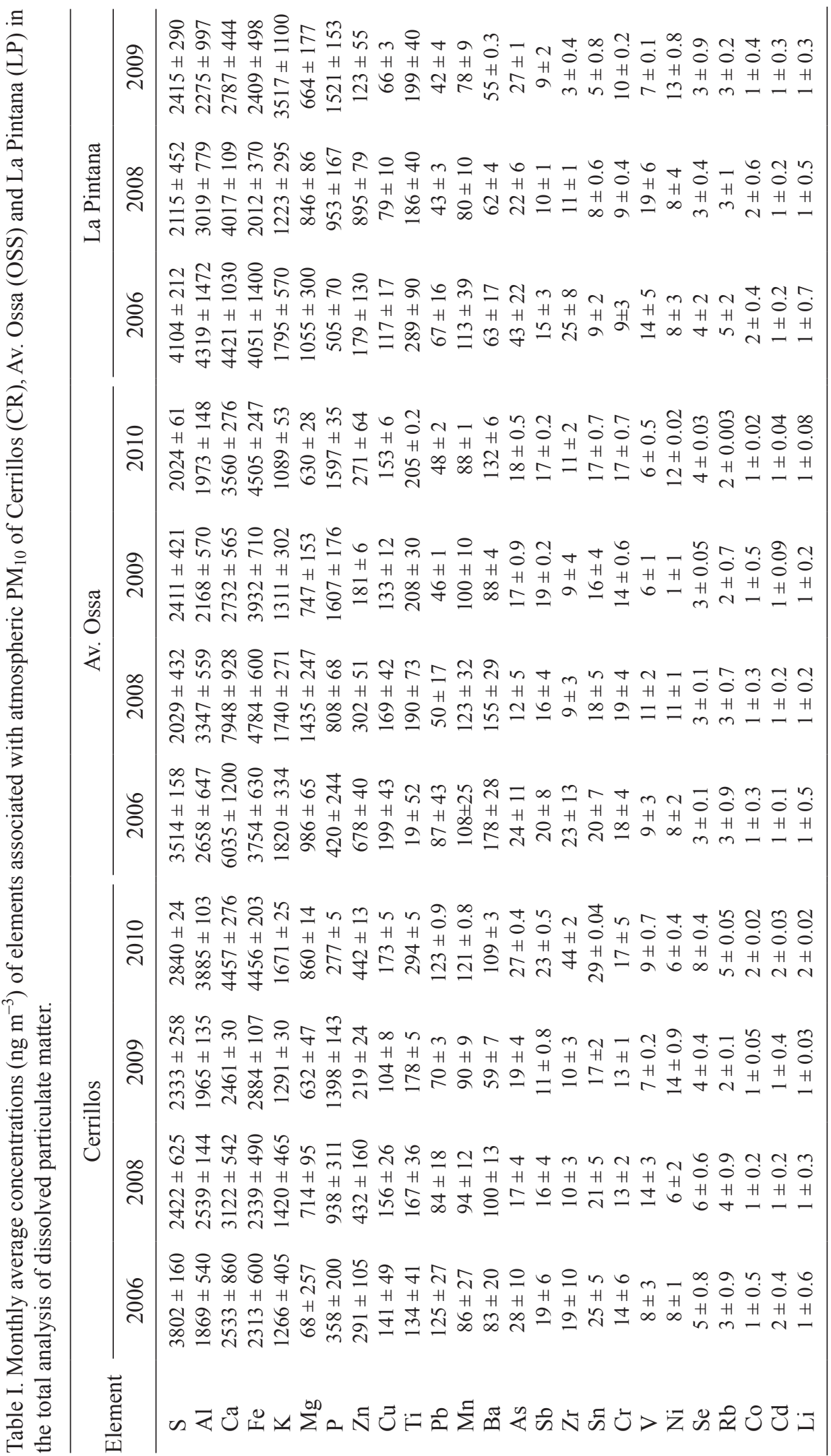


Table II. Concentrations of sulfate, nitrate, chloride and metallic cations; ammonium $\left(\mu \mathrm{Eq} \mathrm{m}{ }^{-3}\right)$, and cation to anion ratios in the water soluble fraction of $\mathrm{PM}_{10}$.

\begin{tabular}{lccccccccc}
\hline Year & $\begin{array}{c}\text { Area of } \\
\text { Santiago }\end{array}$ & Sulfate & Chloride & Nitrate & Ammonium & $\begin{array}{c}\text { Total } \\
\text { anions }\end{array}$ & $\begin{array}{c}\text { Total } \\
\text { metallic } \\
\text { cations }\end{array}$ & $\begin{array}{c}\text { Total } \\
\text { cations }\end{array}$ & $\begin{array}{c}\text { Cation } \\
\text { to anion } \\
\text { ratio }\end{array}$ \\
\hline 2006 & & $0.10 \pm 0.047$ & $0.12 \pm 0.031$ & $0.28 \pm 0.099$ & $0.42 \pm 0.197$ & 0.5 & $0.145 \pm 0.042$ & 0.564 & 1.13 \\
2008 & Cerrillos & $0.06 \pm 0.016$ & $0.09 \pm 0.020$ & $0.28 \pm 0.12$ & $0.29 \pm 0.116$ & 0.43 & $0.184 \pm 0.049$ & 0.474 & 1.10 \\
2009 & $0.06 \pm 0.008$ & $0.13 \pm 0.014$ & $0.23 \pm 0.035$ & $0.24 \pm 0.038$ & 0.42 & $0.156 \pm 0.013$ & 0.396 & 0.94 \\
2010 & & $0.07 \pm 0.001$ & $0.12 \pm 0.014$ & $0.29 \pm 0.015$ & $0.27 \pm 0.0001$ & 0.48 & $0.229 \pm 0.003$ & 0.499 & 1.04 \\
\hline 2006 & & $0.09 \pm 0.048$ & $0.09 \pm 0.028$ & $0.32 \pm 0.124$ & $0.39 \pm 0.203$ & 0.5 & $0.172 \pm 0.054$ & 0.562 & 1.12 \\
2008 & Av. Ossa & $0.05 \pm 0.010$ & $0.08 \pm 0.012$ & $0.38 \pm 0.029$ & $0.36 \pm 0.116$ & 0.51 & $0.160 \pm 0.033$ & 0.520 & 1.02 \\
2009 & & $0.06 \pm 0.012$ & $0.09 \pm 0.015$ & $0.32 \pm 0.005$ & $0.29 \pm 0.018$ & 0.47 & $0.169 \pm 0.018$ & 0.459 & 0.98 \\
2010 & & $0.05 \pm 0.032$ & $0.09 \pm 0.013$ & $0.27 \pm 0.088$ & $0.21 \pm 0.001$ & 0.41 & $0.165 \pm 0.001$ & 0.375 & 0.91 \\
\hline 2006 & & $0.10 \pm 0.050$ & $0.09 \pm 0.010$ & $0.22 \pm 0.060$ & $0.35 \pm 0.179$ & 0.41 & $0.213 \pm 0.061$ & 0.563 & 1.37 \\
2008 & La Pintana & $0.05 \pm 0.024$ & $0.10 \pm 0.008$ & $0.20 \pm 0.078$ & $0.24 \pm 0.054$ & 0.35 & $0.178 \pm 0.052$ & 0.418 & 1.19 \\
2009 & & $0.05 \pm 0.005$ & $0.09 \pm 0.006$ & $0.19 \pm 0.049$ & $0.24 \pm 0.026$ & 0.33 & $0.173 \pm 0.034$ & 0.413 & 1.25 \\
\hline
\end{tabular}

occurs. A common brake-wearing trace component, antimony, is presented in Figure 5d. Concentrations of this element were clearly shifted towards urban sites (CR and OSS) rather than the surburban area (LP), with rather stable values from 2006 to 2010 , maybe slightly increasing in paralell to the vehicle fleet increase. In Figure 5e we plotted $\mathrm{Zn}$ concentrations as an abudant trace element with multiple origins. Industrial and non-exhaust traffic emissions contribute to ambient air concentrations of this trace metal. As seen in the graph, the highest concentrations occurred alternatively in La Pintana in 2008, probably connected to industrial pollution plumes, in Av. Ossa in 2006, or in Cerrillos in 2008 and 2010, mostly related to vehicular emissions. To conclude this section, Figure 5f displays arsenic concentrations, selected as a tracer of industrial emissions. In all sites, but especially in the suburban-industrial site of La Pintana, arsenic concentrations were high (11$43 \mathrm{ng} \mathrm{m}^{-3}$ ), and considering the European standard for this element $\left(6 \mathrm{ng} \mathrm{m}^{-3}\right)$, control measures should be urgently adopted.

\subsection{Cluster analysis: main associations of major and trace PM components}

Our database was not large enough to perform a classical source apportionment analysis. However, alternative statistical treatments such as a cluster analysis may allow us to know the main associations among the elements determined in this study. To this end, we merged all data in a single database and a dendrogram was obtained. The results are shown in Figure 6, where two big groups of elements are separated. The first one, subdivided into two groups, contains $\mathrm{Ti}$ and $\mathrm{Sn}$ on one hand, and $\mathrm{Cr}, \mathrm{Pb}, \mathrm{Co}$ and $\mathrm{Ni}$ on the other. These associations are related to anthropogenic activities, probably fuel-oil combustion emissions ( $\mathrm{Ni}, \mathrm{Co}, \mathrm{Pb}, \mathrm{Cr}$, as seen by Pey et al., 2013) and certain industrial processes (Ti and $\mathrm{Sn})$. The second group of elements is, at the same time, subdivided into two other associations, being the first one characterized by V, Mn, $\mathrm{Cu}$, Se and Sb, which are rather coincident with non-exhaust vehicular emissions from brake and tire abrasion (Pacyna, 1998; Amato et al., 2009; Pey et al., 2010), and the second one by the presence of $\mathrm{Zn}, \mathrm{As}, \mathrm{Ba}$, and $\mathrm{Cd}$, which are mostly linked to industrial processes (Querol et al., 2007); however Ba, and to a lesser extent $\mathrm{Zn}$, are also related to vehicular non-exhaust emissions (Amato et al., 2011). Overall, the dendrogram analysis revealed different anthropogenic emission sources in the Santiago metropolitan area, separating two main groups of particles: one from industrial-related processes and another one more related to vehicular emissions, but somewhat mixed with industrial influences. According to the 2014 emissions inventory, $20 \%$ of the $\mathrm{PM}_{10}$ in Santiago is due to industrial sources, $30 \%$ to wood burning, 


\section{A) Regional PM component}

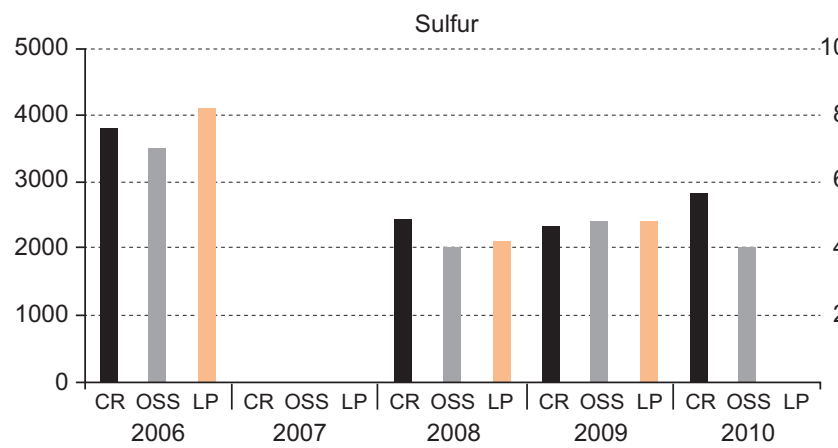

C) Fuel-oil combustion PM components

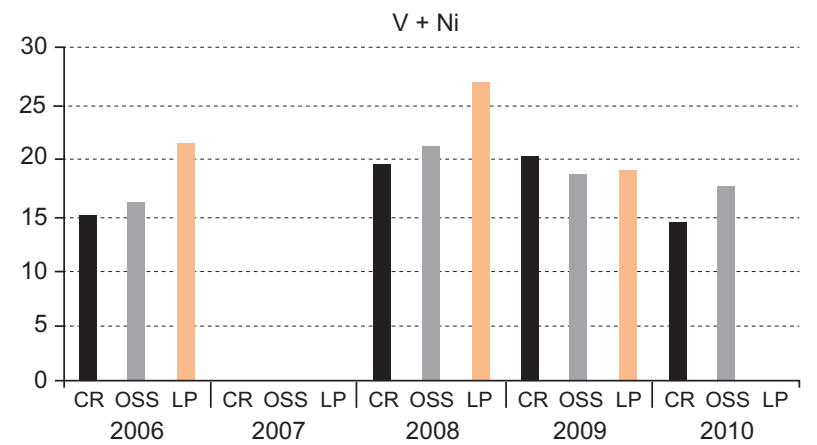

E) Mixedindustrial tracer + traffic related

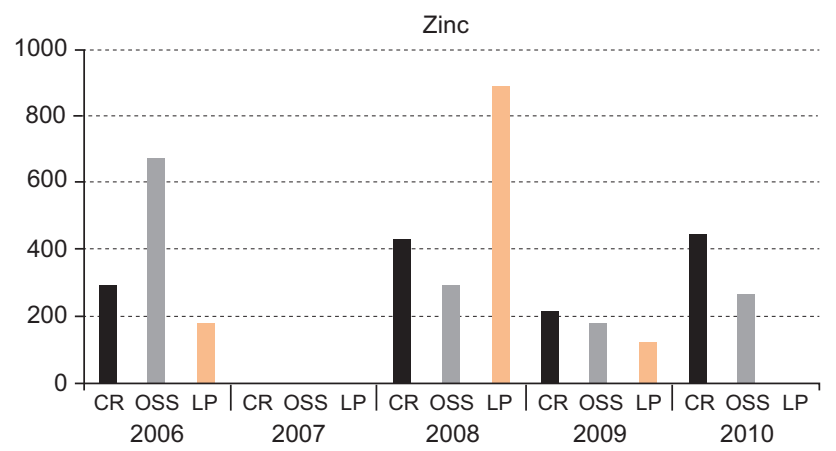

B) Mineral dust PM component

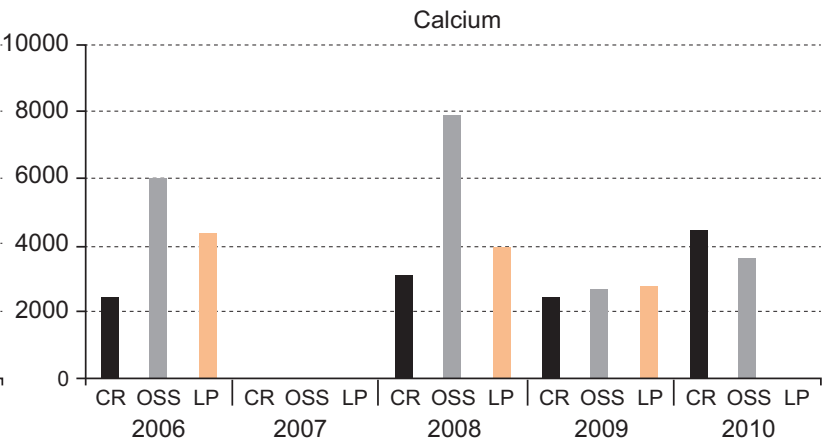

D) Traffic-related PM component (break warning)

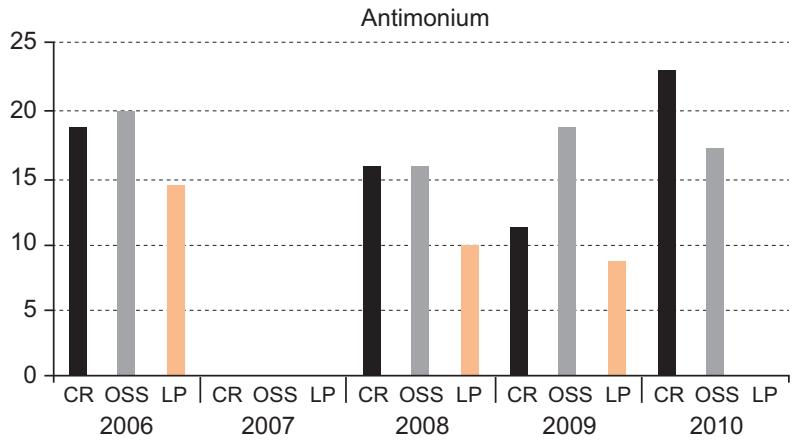

\section{F) Industrial tracer}

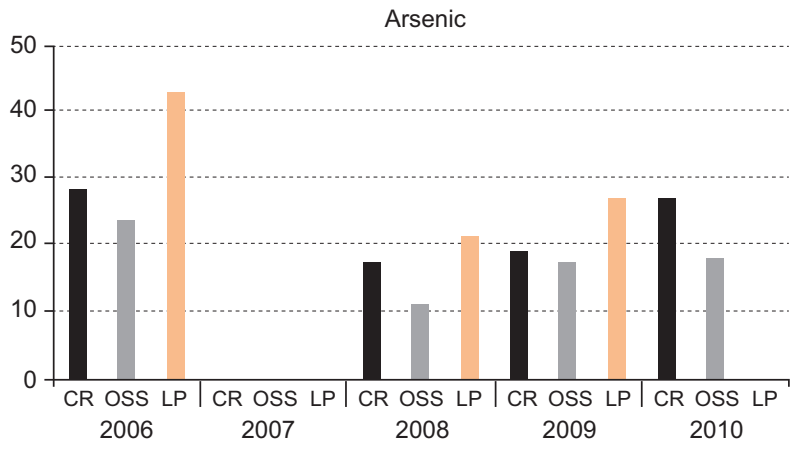

Fig. 5. Temporal and spatial variation of $\mathrm{PM}_{10}$ components associated to important emission sources present in Santiago during May in the years 2006-2010: (a) regional PM component, (b) mineral dust PM component, (c) fuel-oil combustion PM components, (d) traffic-realted PM component (brake wearing), (e) mixed industrial tracer + traffic related component, and (f) industrial tracer. 


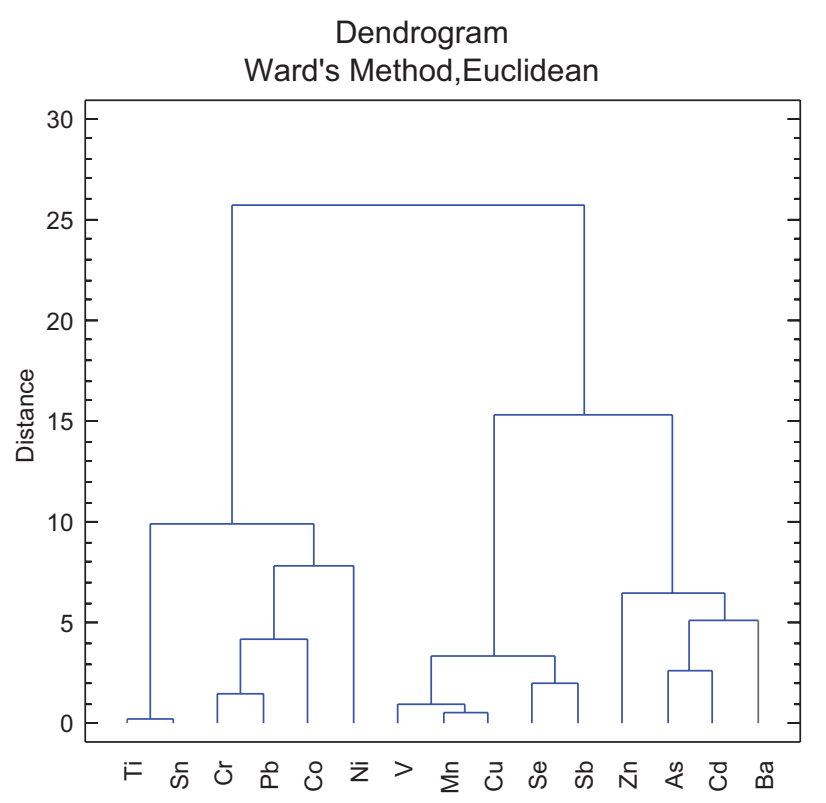

Fig. 6. Results of cluster analysis from the integrated metalic elements database (La Pintana + Av. Ossa + Cerrillos).

$3 \%$ to agricultural burning, and $44 \%$ to mobile sources (MMA, 2014). An extended study covering all seasons and incorporating other chemical determinations would be desirable to fully investigate the real sources and their contributions, which is absolutely necessary to develop and implement adequate mitigation strategies.

\subsection{Soluble elements}

$\mathrm{PM}_{10}$ samples were subjected to water extraction to determine the degree of solubility of major and trace metals in order to determine its lability in Santiago's atmosphere.

Table III shows monthly average concentrations for each site and year of major and trace elements. By combining the information presented in Tables I and III we were able to prepare Figure 5, in which the soluble/insoluble partitioning mass concentration of each of the elements determined in this study is shown. After sulfur, clearly shifted towards the soluble fraction $(>90 \%$ of the total mass was found as soluble compounds), specific trace elements such as $\mathrm{Ba}, \mathrm{Sb}, \mathrm{Cd}, \mathrm{As}$, and $\mathrm{Zn}$ displayed a significant water-soluble content, with $50 \%$ to $73 \%$. Keeping in mind that some of these elements are considered toxic and/or carcinogenic (As, $\mathrm{Cd}$ and $\mathrm{Zn}$ ) to human beings (Hughes, 2002; Lafuente, 2013), our results are even more relevant. It has been found that the urban atmosphere of Santiago is highly enriched in trace elements, some of them highly soluble and therefore with a higher toxicological potential with respect to other less soluble or practically insoluble. On the other hand, $\mathrm{Al}, \mathrm{Mg}, \mathrm{Zr}, \mathrm{Ti}, \mathrm{Sn}, \mathrm{Cr}$, and $\mathrm{Pb}$ showed a preference for the non-soluble fraction, with relative abundances of $75-99 \%$.

Comparing our results from the Cerrillos station with those obtained by Richter et al. (2007), the solubility percentages are quite comparable (As, 70\% soluble in our study against $60 \%$ in the aforementioned article; $\mathrm{Pb}$, about $15 \%$ in our work against $40 \%$ in the previous decade).

The results on solubility, besides providing information on the lability in the respiratory system, may give some indications about possible chemical states of the species, i.e., the kinds of salts present in PM. For example, water-soluble $\mathrm{Zn}$ is usually found in the form of zinc sulfate, while in the residual fraction it is commonly found as zinc oxide, frequently joined with $\mathrm{Fe}$ and $\mathrm{Mn}$, carbonates, or aluminates (Dos Santos et al., 2009). Likewise, water-soluble $\mathrm{Cu}$ is usually encountered as copper sulfate, while the residual fraction is mostly linked to sulfides or silicates.

Overall, the atmosphere of Santiago is rich in soluble and insoluble major and trace metals. Most of them are associated with industrial and road-traffic emissions, especially non-exhaust emissions from brake and tire wearing and pavement abrasion. Santiago's inhabitants are exposed to high heavy metal concentrations, at least during the cold season.

The amount of soluble major and trace elements together with the amount of typical anions and cations (Tables II and III) is near $50 \%$ of the $\mathrm{PM}_{10}$ mass.

The results from the cluster analysis in Figure 6 give an approximate composition of the sources responsible for the measured PM. Figure 8 gives the concentration of soluble elements according to these sources separated according to the sites. It is found in Figure 8a that La Pintana has a higher concentration of crustal elements $(\mathrm{Ca}, \mathrm{K}, \mathrm{Mg}$ and $\mathrm{Al}$ ), which is due to the fact that this site is located towards the south of Santiago (see Fig. 1), far from downtown, thus it receives more influence from rural environments. Exhaust and fuel oil emissions do not show a preferred trend and all stations have similar 


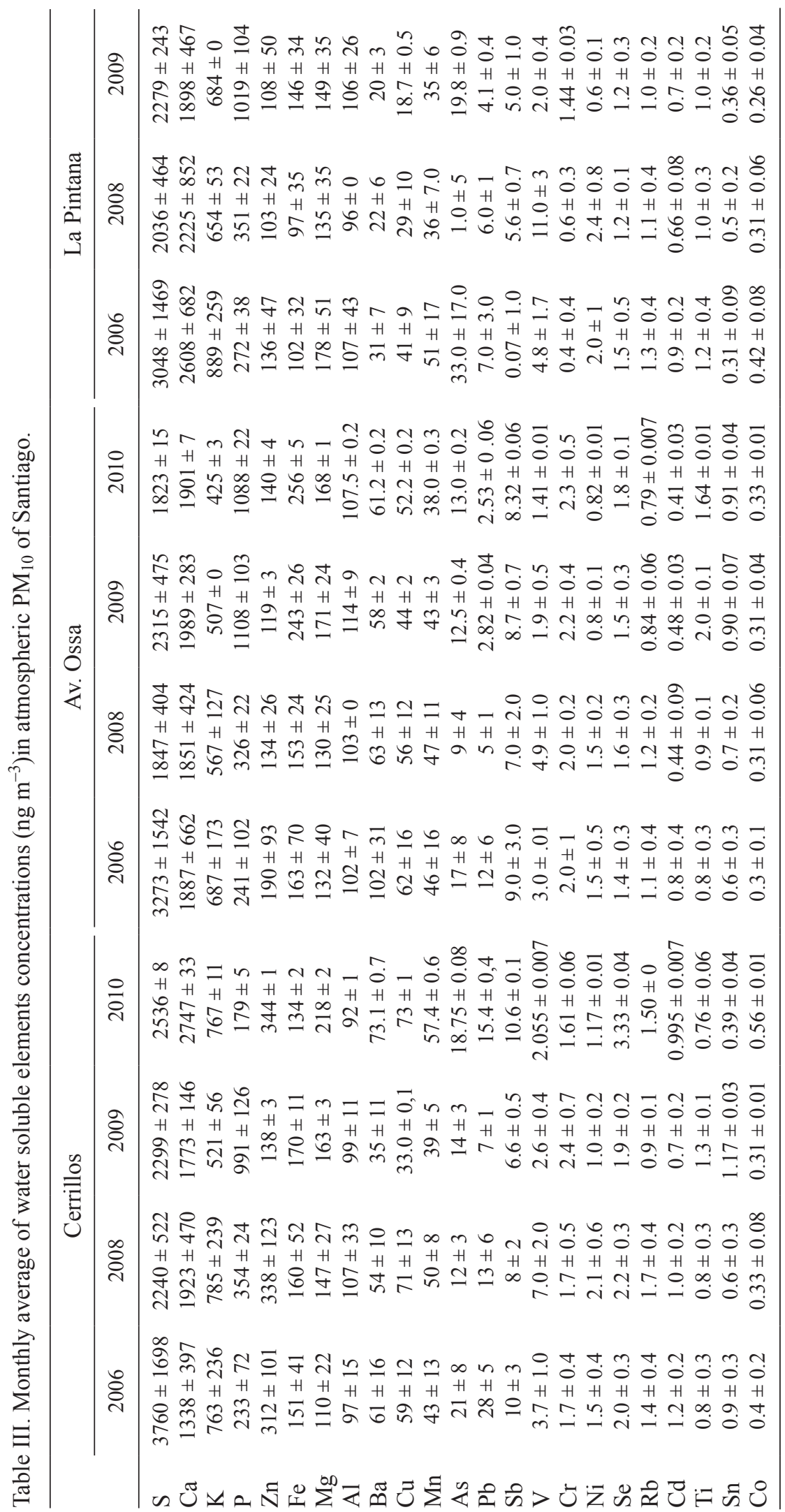




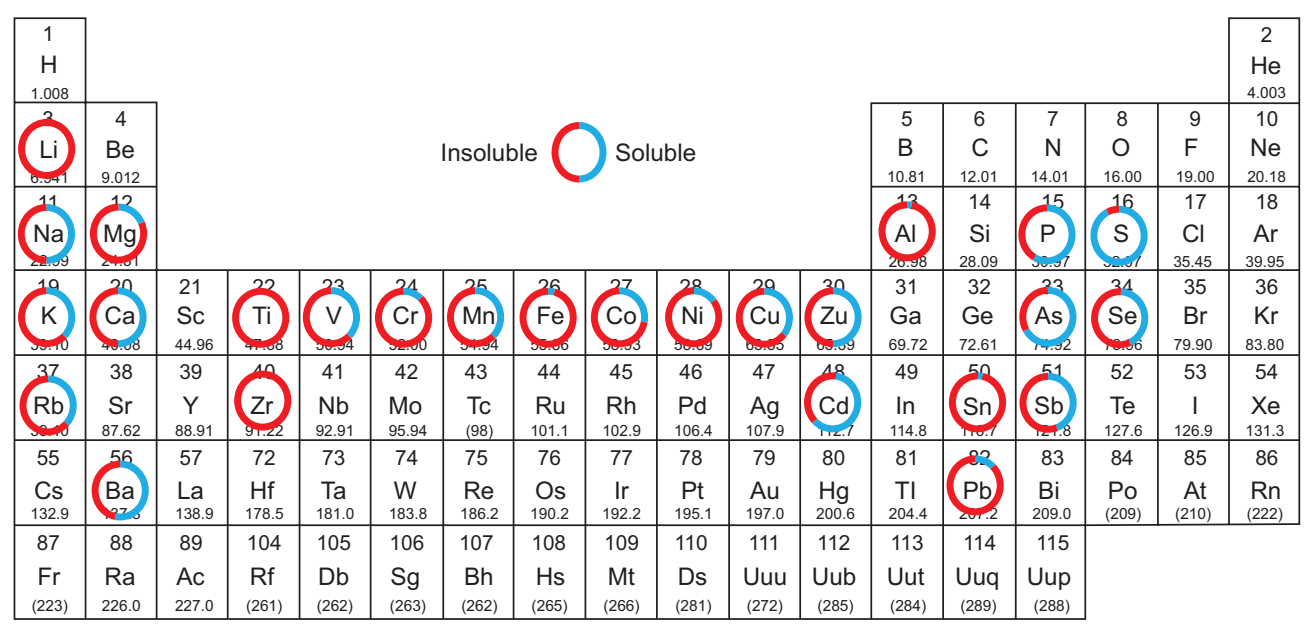

Fig. 7. Partitioning of soluble/insoluble concentrations of the determined elements.
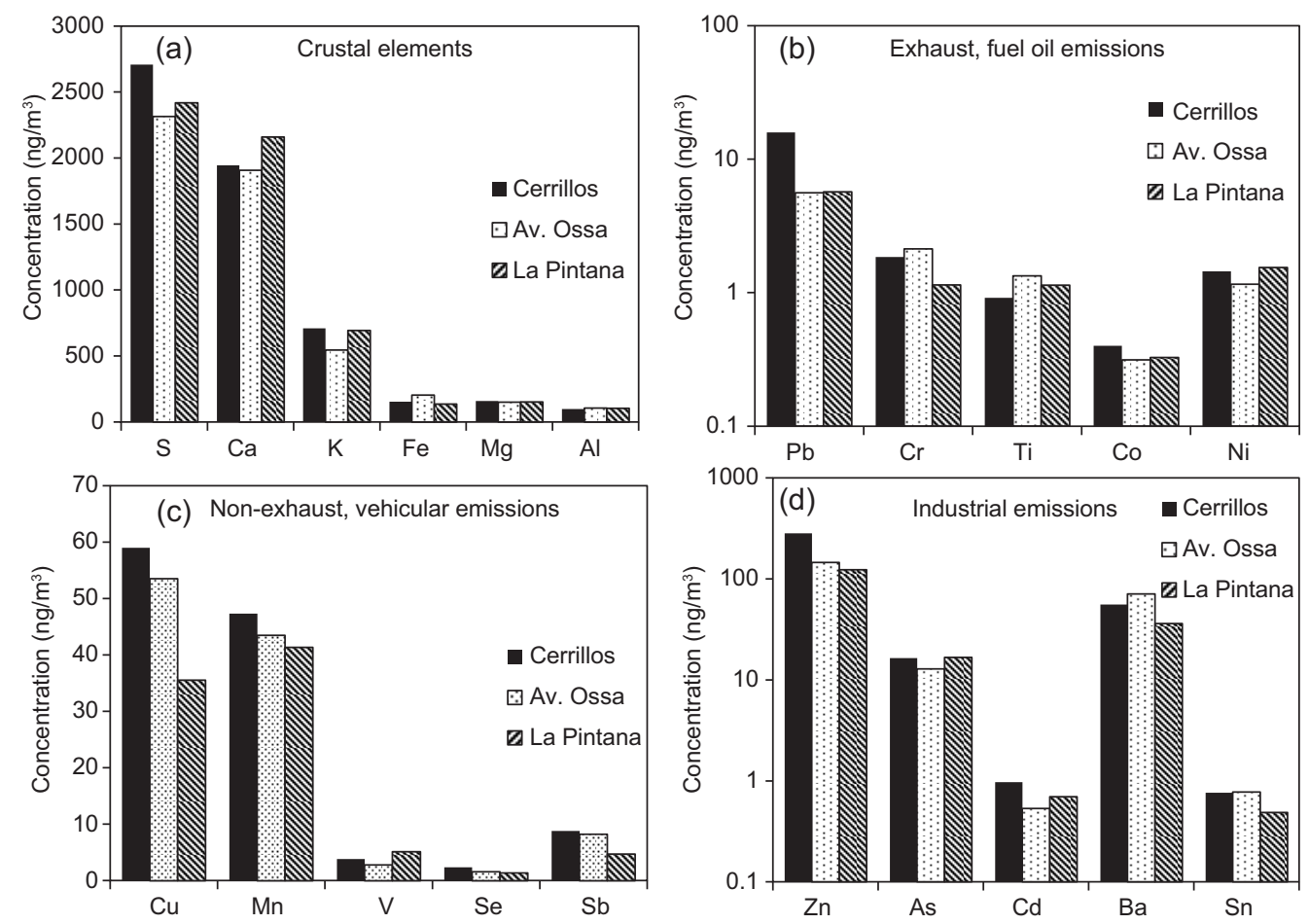

Fig. 8. Soluble components of $\mathrm{PM}_{10}$ associated with different sources in the three sites. (a) Crustal elements, (b) exhaust and fuel oil emissions, (c) non-exhaust emissions, (d) industrial emissions.

concentrations from this source. This figure indicates that exhaust emissions are well distributed over the city, which can be explained because mobile sources are spread out. Non-exhaust vehicular emissions seem to be higher in Cerrillos although $\mathrm{Cu}$ and $\mathrm{Mn}$ could also be generated in industrial processes. Industrial emissions are shown in Figure 8d, which also seem to be higher in Cerrillos. This can be explained because in this sector there are several large industries and many small auto repair and paint shops.

\section{Conclusions}

The inhabitants of Santiago are exposed to high $\mathrm{PM}_{10}$ pollution, which ranged from $71 \mu \mathrm{g} \mathrm{m}^{-3}$ (Cerrillos) to $128 \mu \mathrm{g} \mathrm{m}^{-3}$ (La Pintana), associated mainly with 
the vehicular traffic present in the city. In Santiago the central and peripheral urban zones are subjected to the same levels of $\mathrm{PM}_{10}$ and its heavy metal load.

The levels of As and Cd, which are reported to be toxic to human health, had high solubility in $\mathrm{PM}_{10}$, showing that breathable $\mathrm{PM}_{10}$ is very noxious to the inhabitants of Santiago. The As levels exceed the environmental quality standard. One of the sites (Cerrillos) was clearly influenced from industrial sources because it had higher levels of $\mathrm{Zn}$, As and $\mathrm{Cd}$.

The soluble or labile fraction, which is the really important one regarding breathable pollution, had high levels of the species in the form of nitrates, chlorides, and sulfates of $\mathrm{Cd}, \mathrm{Zn}, \mathrm{Ba}, \mathrm{As}$, and $\mathrm{Sb}$. The soluble fraction of $\mathrm{Ba}, \mathrm{Sb}, \mathrm{Cd}, \mathrm{As}$, and $\mathrm{Zn}$, which are generated mainly from industrial sources, ranged from $50 \%$ to $73 \%$. The chemical species associated with $\mathrm{Zn}$ and with $\mathrm{NO}_{3}{ }^{-}$were the most soluble.

These results call for a long-term study of PM composition and sources in Santiago which will serve a double purpose: (1) surveillance of the government air quality mitigation plan and its effectiveness, and (2) creation of a database for further epidemiological studies including sources and/or chemical species and their contributions.

\section{Acknowledgments}

Funding from different projects supported this study: Fondecyt 1170456, 1151117 and CONICYT by the doctoral scholarship of Karen Sánchez grant 24129966. Most of the analytical costs were covered by different research projects from the Spanish Ministry of Science and Innovation (CARIATI- CGL200806294/CLI, CGL2007-62505/CLI, GRACCIECSD2007-00067). J. Pey currently benefits from a Ramón y Cajal Research Grant (RYC-2013-14159) from the Spanish Ministry of Economy and Competitiveness.

\section{References}

Amato F., Pandolfi M., Escrig A., Querol X., Alastuey A., Pey J., Pérez N. and Hopke P., 2009. Quantifying road dust resuspension in urban environment by Multilinear Engine: a comparison with PMF2. Atmos. Environ. 43, 2770-2780.

DOI: $10.1016 /$ j.atmosenv.2009.02.039
Amato F., Viana M., Richard A., Furger M., Prévôt A.S.H., Nava S., Lucarelli F., Bukowiecki N., Alastuey A., Reche C., Moreno T., Pandolfi M., Pey J. and Querol X., 2011. Size and time-resolved roadside enrichment of atmospheric particulate pollutants. Atmos. Chem. Phys. 6, 2917-2931.

DOI: $10.5194 / \mathrm{acp}-11-2917-2011$

Artaxo P., Oyola P. and Martínez R. 1999. Aerosol composition and source apportionment in Santiago de Chile. Nucl. Instrum. Methods 150, 409-416.

DOI: 10.1016/S0168-583X(98)01078-7

Bell M.L., Ebisu K., Peng R., Samet J.M. and Dominici F., 2009. Hospital admissions and chemical composition of fine particle air pollution. Am. J. Resp. Crit. Care Med. 179, 1115-1120.

DOI: $10.1164 / \mathrm{rccm} .200808-1240 \mathrm{OC}$

Cakmak S., Dales R. and Blanco C., 2007. Air pollution and mortality in Chile: Susceptibility among the elderly. Environ. Health Persp. 115, 524-527.

DOI: 10.1289/ehp.9567

Cakmak S., Dales R., Blanco C., Fernández M., Rubio M.A. and Oyola P., 2009. Components of particulate air pollution and emergency department visits in Chile. Arch. Environ. Occup. H. 64, N3, 148-155.

DOI: $10.1080 / 19338240903240228$

Cakmak S., Dales R., Rubio M.A. and Blanco C., 2011. The risk of dying on days of higher air pollution among the socially disadvantaged elderly. Environ. Res. 111, 388-93.

DOI: 10.1016/j.envres.2011.01.003

Cheng Y., Engling G., He K-B., Duan F.-K., Ma Y.-L., Du Z.-Y., Liu J.-M., Zheng M. and Weber R.J., 2013. Biomass burning contribution to Beijing aerosol. Atmos. Chem. Phys. 13, 7765-7781.

DOI: /10.5194/acp-13-7765-2013

Didyk B., Simoneit B.R., Pezoa L., Riveros M. and Flores A., 2000. Urban aerosol particles of Santiago, Chile. Atmos. Environ. 34, 1167-1179.

DOI: $10.1016 / \mathrm{S} 1352-2310(99) 00403-3$

Dos Santos M., Gómez D., Dawidowski L., Goutier E. and Smichowski P., 2009. Determination of water-soluble and insoluble compounds in size classified airborne particulate matter. Microchem. J. 91, 133-139.

DOI: 0.1016/j.microc.2008.09.001

Figuero E., Gómez-Lobos A., Jorquera P. and Labrín F., 2017. Los impactos del Transantiago en la contaminación atmosférica de Santiago. Una estimación econométrica. Sociedad Chilena de Políticas Públicas. 
Available at: https://www.sociedadpoliticaspublicas. cl/archivos/BLOQUEM/Vivienda_Transporte_Desafios_Sectoriales/Los_impactos_del_Transantiago_ en_la_contaminacion_de_Santiago.pdf(last accessed on August 2018).

Franklin M., Koutrakis P. and Schwartz J., 2008. The role of particle composition on the association between $\mathrm{PM}_{2.5}$ and mortality. Epidemiology 19, 680-689.

DOI: 10.1097/EDE.0b013e3181812bb7

Gil L., King L. and Adonis M., 2000. Trends of polycyclic aromatic hydrocarbon levels and mutagenic in Santiago's inhalable airborne particles in the period 1992-1996. Inhal. Toxicol. 12, 1185-1204.

DOI: $10.1080 / 08958370050198539$

Gramsch E., Cereceda-Balic F., Oyola P. and von Baer D., 2006. Examination of pollution trends in Santiago de Chile with cluster analysis of $\mathrm{PM}_{10}$ and ozone data. Atmos. Environ. 40, 5464-5475.

DOI: $10.1016 /$ j.atmosenv.2006.03.062

Gramsch E., Gidhagen L., Wahlin P., Oyola P., Moreno F., 2009. Predominance of soot-mode ultrafine particles in Santiago de Chile: Possible sources. Atmos. Environ. 43, 2260-2267.

DOI: 10.1016/j.atmosenv.2009.01.047

Gramsch E., Le Nir, G., Araya M., Rubio M.A., Moreno

F. and Oyola P., 2013. Influence of large changes in public transportation (Transantiago) on the black carbon pollution near streets. Atmos. Environ. 65, 153-163.

DOI: $10.1016 /$ j.atmosenv.2012.10.006

Hughes M., 2002. Arsenic toxicity and potential mechanisms of action. Toxicol. Lett. 133, 1-16.

DOI: $10.1016 / \mathrm{S} 0378-4274(02) 00084-\mathrm{X}$

INE, 2011, Annual report of motorized vehicles in Chile. Available at: historico.ine.cl/canales/chile_estadistico/ estadisticas_economicas/transporte_y_comunicaciones/parquevehiculos.php (last accessed on May 2018).

INE, 2017. Censo 2017. Instituto Nacional de Estadística, Chile. Available at: http://www.censo2017.cl/.

Jorquera H., 2002. Air quality at Santiago, Chile a box modeling approach II. $\mathrm{PM}_{2.5}$, coarse and $\mathrm{PM}_{10}$ particulate matter fractions. Atmos. Environ. 36, 331-344. DOI: $10.1016 / \mathrm{S} 1352-2310(01) 00418-6$

Jorquera H. and Barraza F., 2012. Source apportionment of ambient $\mathrm{PM}_{2.5}$ in Santiago, Chile: 1999 and 2004 results. Sci. Total Environ. 435-436, 418-429.

DOI: $10.1016 /$ j.scitotenv.2012.07.049
Koutrakis P., Sax S., Sarnat J., Coull B., Demokritou P., Oyola P., García J. and Gramsch E., 2005. Analysis of $\mathrm{PM}_{10}, \mathrm{PM}_{2.5}$ and $\mathrm{PM}_{2.5-10}$ concentrations in Santiago, Chile from 1989 to 2001. J. Air Waste Man. 55, 342351. DOI: $10.1080 / 10473289.2005 .10464627$

Lafuente A., 2013. The hypothalamic-pituitary-gonadal axis in target of cadmium toxicity. An update of recent studies and potential therapeutic approaches. Food Chem. Toxicol. 59, 395-404.

DOI: $10.1016 /$ j.fct.2013.06.024

Mena-Carrasco M., Saide P., Delgado R., Hernández P., Spak S., Molina L., Carmichael G. and Jiang X., 2014. Regional climate feedbacks in central Chile and their effect on air quality episodes and meteorology. Urban Climate 10, 771-781.

DOI: $10.1016 /$ j.uclim.2014.06.006

MMA, 2014. Actualización y sistematización del inventario de emisiones de contaminantes atmosféricos en la Región Metropolitana, 2014. Ministerio del Medio Ambiente, Chile. Available at: http://ambiente.usach. cl/estudios/estudios.html (last accessed on May 2018).

Molina M. and Molina L., 2004. Megacities and atmospheric pollution. J. Air Waste Manage. 54, 644-680. DOI: $10.1080 / 10473289.2004 .10470936$

Moreno F., Gramsch E., Oyola P. and Rubio M.A., 2010. Modification in the soil and traffic related sources of particle matter between 1998 and 2007 in Santiago de Chile. J. Air Waste Manage. 60, 1410-1421.

DOI: $10.3155 / 1047-3289.60 .12 .1410$

Ostro B., Tobías A., Querol X., Alastuey A., Amato F., Pey J., Pérez N., Borrell C. and Sunyer J., 2011. The effects of particulate matter sources on daily mortality: A case-crossover study of Barcelona, Spain. Environ. Health Persp. 119, 1781-1787.

DOI: $10.1289 / \mathrm{ehp} .1103618$

Pacyna J.M., 1998. Source inventories for atmospheric trace metals in atmospheric particles. In: Atmospheric particles (Harrison R.M. and van Grieken R.E., Eds.). John Wiley and Sons, 385-424 (IUPAC Series on Analytical and Physical Chemistry Environmental Systems, 5).

Paris R., Desboeufs K.V., Formenrti P., Nava S. and Chou C., 2010. Chemical characterisation of iron in dust and biomass burning aerosols during AMMA-SOPO/ DABEX: Implication for iron solubility. Atmos. Chem. Phys. 10, 4273-4282. DOI: 10.5194/acp-10-4273-2010 Peng R., Bell M., Geyh A., McDermott A., Zeger S., Samet J. and Dominici F., 2009. Emergency admissions for 
cardiovascular and respiratory diseases and the chemical composition of fine particle air pollution. Environ. Health Persp. 117, 957-963.

DOI: 10.1289/ehp.0800185

Pey J., Querol X. and Alastuey A., 2010. Discriminating the regional and urban contributions in the north-western Mediterranean: PM levels and composition. Atmos. Environ. 44, 1587-1596.

DOI: 10.1016/j.atmosenv.2010.02.005

Pey J., Pérez N., Cortez J., Alastuey A. and Querol X., 2013. Chemical fingerprint and impact of shipping emission over a western Mediterranean metropolis: primary and aged contributions. Sci. Total Environ. 463463, 497-507. DOI: 10.1016/j.scitotenv.2013.06.061

Pope C.A. III and Dockery D.W., 2006. Health effects of fine particulate air pollution: lines that connect. J. Air Waste Mana. 56, 709-742. DOI: $10.1080 / 10473289.2006 .10464485$

Prendez M., Ortiz J., Cortez E. and Cassorla V., 1984. Elemental composition of airborne particulate matter from Santiago city, Chile. JAPCA J. Air Poll. Control Ass. 4. 54-56. DOI: $10.1080 / 00022470.1984 .10465726$

Querol X., Viana M., Alastuey A., Amato F., Moreno T., Castillo S., Pey J., de la Rosa J., Sánchez de la Campa A., Artiñano B. and Salvador P., 2007. Source origin of trace elements in PM from regional background urban and industrial sites of Spain. Atmos. Environ. 41, 7219-7231. DOI: 10.1016/j.atmosenv.2007.05.022

Richter P., Griño P., Ahumada I. and Giordano A., 2007. Total element concentration and chemical fractionation in airborne particulate matter from Santiago, Chile. Atmos. Environ. 41, 6729-6738.

DOI: $10.1016 /$ j.atmosenv.2007.04.053

Sarnat J.A., Marmur A., Klein M., Kim M., Russell A.G., Sarnat S.E., Mulholland J.A., Hopke P.K. and Tolbert P.E., 2008. Fine particle sources and cardiorespiratory morbidity: an application of chemical mass balance and factor analytical source-apportionment methods. Environ. Health Persp. 116, 459-466.

DOI: $10.1289 /$ ehp. 10873

Sax S., Koutrakis P., Ruiz P., Cereceda-Balic F. and Gramsch E., 2007. Trend in elemental composition of fine particulate matter in Santiago, Chile from 19982003. J. Air Waste Manage. 57, 845-855.

DOI: $10.3155 / 1047-3289.57 .7 .845$
Seguel R., Morales R.G.E. and Leiva M., 2009. Estimation of primary and secondary organic carbon formation in $\mathrm{PM}_{2.5}$ aerosols of Santiago City, Chile. Atmos. Environ. 43, 2125-2131.

DOI: $10.1016 /$ j.atmosenv.2009.01.029

SINCA, 2018. Sistema de Información Nacional de Calidad del Aire. Ministerio del Medio Ambiente, Chile. Available at: https://sinca.mma.gob.cl/.

Toro R., Morales R.G., Canales S., González-Rojas C. and Leiva M., 2014. Inhaled and inspired particulate in Metropolitan Santiago, Chile exceed air quality standards. Build. Environ. 79, 115-123.

DOI: 10.1016/j.buildenv.2014.05.004

Troncoso R., de Grange L. and Cifuentes L., 2012. Effects of environmental alerts and pre-emergencies on pollutant concentrations in Santiago, Chile. Atmos. Environ. 61, 550-557.

DOI: $10.1016 /$ j.atmosenv.2012.07.077

Ulrich A., Wilchser A., Hess A., Heeb N., Emmenegger L. and Czerwinski J., 2012. Particle and metal emissions of diesel and gasoline engines. Are particle filters appropiate measures. In 16th conference on combustion generated nanoparticles. Zurich, Switzerland.

Valdés A., Zanobetti A., Halonen J.I., Cifuentes L., Morata D. and Schwartz J., 2012. Elemental concentrations of ambient particles and cause specific mortality in Santiago, Chile: A time series study. Environ. Health 11, 82. DOI: $10.1186 / 1476-069 x-11-82$

Villalobos A.M., Barraza F., Jorquera H. and Schauer J.J., 2015. Chemical speciation and source apportionment of fine particulate matter in Santiago, Chile. Sci. Total. Environ. 512-513, 133142.

DOI: $10.1016 /$ j.scitotenv.2015.01.006

WHO, 2013. Public health, environmental and social determinants of health (PHE). World Health Organization. Available at: http://www.who.int/phe/health_topics/ outdoorair/databases/en/index.html.

Wang R., Balkanski Y., Boucher O., Ciais P., Peñuelas J. and Tao S., 2015. Significant contribution of combustion related emissions to the atmospheric phosphorus budget. Nat. Geosci. 8, 48-54.

DOI: $10.1038 /$ ngeo2324 